\title{
Anatomical characterisation of the kidneys of Didelphis aurita (Didelphimorphia: Didelphidae)
}

\author{
S.V. Peçanha1', R. Dünkel-Duarte1, F.C.S. Bernardes², T.M. Estruc ${ }^{1}$, R.M. do Nascimento', \\ C.A. dos Santos-Sousa ${ }^{1,3}$, P. de Souza Junior ${ }^{2}$, M. Abidu-Figueiredo' \\ ${ }^{1}$ Federal Rural University of Rio de Janeiro, Seropedica, Brazil \\ ${ }^{2}$ Federal University of Pampa, Uruguaiana, Brazil \\ ${ }^{3}$ Federal University of Acre, Rio Branco, Brazil \\ [Received: 2 October 2019; Accepted: 19 January 2020]
}

Background: Didelphis aurita is a marsupial with wide distribution in the South American continent and highly adapted to urban centres. The objective of this study was to describe the measurements and skeletopy of the kidneys and renal vascularisation of this species.

Materials and methods: With this aim, 29 cadavers (14 males and 15 females) of D. aurita collected on highways were analysed. The rostrum-sacral length of specimens, kidney measurements (length, width and thickness) and the length of the renal vessels were measured and the renal skeletopy registered.

Results: In the right kidney, average length, width, thickness and ellipsoid volume were $28.6 \pm 5.0 \mathrm{~mm}, 15.6 \pm 2.9 \mathrm{~mm}, 12.8 \pm 3.0 \mathrm{~mm}$ and $3.3 \pm$ $\pm 2.4 \mathrm{~cm}^{3}$, respectively; in the left kidney, $31.0 \pm 3.8 \mathrm{~mm}, 14.5 \pm 3.6 \mathrm{~mm}$, $12.6 \pm 2.6 \mathrm{~mm}$ and $3.2 \pm 2.2 \mathrm{~cm}^{3}$, respectively. There was no significant difference in the comparison of averages of renal dimensions between sexes and between antimeres. The right renal artery $(13.2 \pm 2.6 \mathrm{~mm})$ was significantly longer $(p<0.01)$ than the left renal artery $(10.7 \pm 2.3 \mathrm{~mm})$. In contrast, the left renal vein $(13.9 \pm 3.5 \mathrm{~mm})$ was longer $(p<0.01)$ than the right renal vein $(7.0 \pm 2.3 \mathrm{~mm})$. The skeletopy of the right kidney predominated between T13-L1 in 58.6\% of the cases and the skeletopy of the left kidney between $L 1-L 3$ in $41.4 \%$. The average length of the kidneys corresponded to $6 \%$ to $8 \%$ of the rostrum-sacral length of the specimens.

Conclusions: The data of the present study characterised the measurements and topography of kidneys and renal vessels in D. aurita and can support the interpretation of clinical, experimental and pathological findings in this species. (Folia Morphol 2020; 79, 4: 805-810)

Key words: animal anatomy, big-eared opossum, marsupial, nephrology, urogenital system

\section{INTRODUCTION}

The opossums are marsupials of the order Didelphimorphia, family Didelphidae, genus Didelphis Linnaeus, 1758. On the American continent, they are distributed from southern Canada to the central part of Argentina, in a wide variety of habitats, from flat areas to mountainous regions $[14,33]$. Six species were described in the genus: Didelphis marsupialis

Address for correspondence: Prof. P. de Souza Junior, Laboratory of Animal Anatomy, Rodovia BR-472, Km 595, Uruguaiana, RS, Brazil, Postal code 97501-970, tel/fax: +55 55 3911-0200, e-mail: paulosouza@unipampa.edu.br 
(Linnaeus, 1758), D. virginiana (Kerr, 1792), D. aurita (Wied-Neuwied, 1826), D. albiventris (Lund, 1840), $D$. pernigra (Allen, 1900), and D. imperfecta (Mondolfi and Pérez-Hernández, 1984) [13, 18, 24].

The species Didelphis aurita, known as big-eared opossum, is distributed in the east, midwest and south of Brazil, Paraguay and Argentina $[3,4,6,13,22]$. It is abundant throughout its area of coverage, with great ecological plasticity and good adaptation to urban centres $[5,15]$.

The kidneys are a pair of structures, retroperitoneal, compressed against the dorsal abdominal wall of both sides of the spine. Predominantly located in the sublumbar region, they can protrude cranially under the last ribs $[2,17]$. The knowledge of topography and renal measurements is fundamental in the diagnosis of kidney diseases. Some renal pathologies determine changes in renal size due to hypertrophic or atrophic processes [9]. In humans it was established that size and mass of the kidneys vary according to sex, also, it was established that the left kidney was larger than the right one [20].

Specimens of the Didelphidae family have been used as alternatives for animal experimentation, including researches on the urogenital system $[8,19,31]$. Even so, data on measurements and vascularisation of the kidneys are scarce for this species. Therefore, the objective of this study is to describe kidney measurements and renal pedicle in specimens of $D$. aurita and contribute to the diagnosis of nephropathies and interpretation of experimental findings in this species.

\section{MATERIALS AND METHODS}

The present study was approved by the Animal Use Ethics Committee of Federal Rural University of Rio de Janeiro (number 018/2017). Twenty-nine (14 males and 15 females) adult specimens of $D$. aurita were dissected with no evidence of renal alterations on macroscopic examination. The corpses were collected after roadkill on highways of Serra dos Órgãos, Rio de Janeiro, Brazil. Samples with advanced stage signs of autolysis were discarded from this study.

Initially the specimens were sexed, identified and had their rostrum-sacral length measured. Then, the thoracic aorta artery was dissected and cannulated. The arterial system was flushed with $0.9 \%$ sodium chloride and then fixed with $10 \%$ formaldehyde solution. After formaldehyde infusion, a latex solution (Petrolátex S-65, Refinery Duque de Caxias-REDUC-Petrobras, Duque de Caxias-RJ) was injected, diluted 1:1 with red dye $\left(x a d r e z^{\circledR}\right)$. Finally, the corpses were immersed in low density polyethylene boxes containing $10 \%$ formaldehyde solution to complete the fixation process.

After at least 7 days of fixation, the cadavers had the peritoneal cavity open and the kidneys and renal vessels dissected. Next, the skeletopy of the kidneys was determined in relation to the vertebrae. In order to determine skeletopy, part of the hipaxial musculature was removed until the articulation of the last pair of ribs with the last thoracic vertebra and lumbar transverse processes were identified. Skeletopy was defined between the cranial and the caudal pole of each kidney.

A calliper $(0-150 \mathrm{~mm}, 0.01 \mathrm{~mm}$ resolution, accuracy $\pm 0.02 \mathrm{~mm}, \mathrm{Eda}^{\circledR}$ ) was used to measure the dimensions of the kidneys and their vessels. In the kidneys, the craniocaudal length, the medial-lateral width and the dorsal-ventral thickness were measured. In the vessels was measured the length. The ellipsoid volume of each kidney was calculated by the equation (length $\times$ width $\times$ thickness $\times 0.5236$ ), as established previously by other study [26].

\section{Statistical analysis}

Data were tabulated in spreadsheets and expressed as arithmetic mean and standard deviation. Unpaired Student's t-test was used to compare means between sexes and antimeres. Chi-square test was used to verify if there was a difference between left and right kidney skeletopy. Pearson's linear correlation was performed to observe the correlation between the rostrum-sacral length and the renal dimensions. The value of $p<0.05$ was considered significant. The analysis was performed in the Graphpad Prism $5^{\circledR}$ software.

\section{RESULTS}

In all the individuals the renal arteries emerged directly from the abdominal aorta as a single vessel and emitted branches to the adrenal and ureter. The renal veins drained directly into the caudal vena cava in all the animals, except for one female whose left renal vein was double (Fig. 1).

The average rostrum-sacral length of the animals was $42.2 \pm 5.6 \mathrm{~cm}, 42.0 \pm 5.1 \mathrm{~cm}$ in males and $42.4 \pm 6.2 \mathrm{~cm}$ in females, with no significant difference between sexes $(p=0.84)$.

The right kidney presented a format that resembles a "bean seed". The left kidney had a longer elliptical shape. The kidneys were brownish, pale, smooth in 


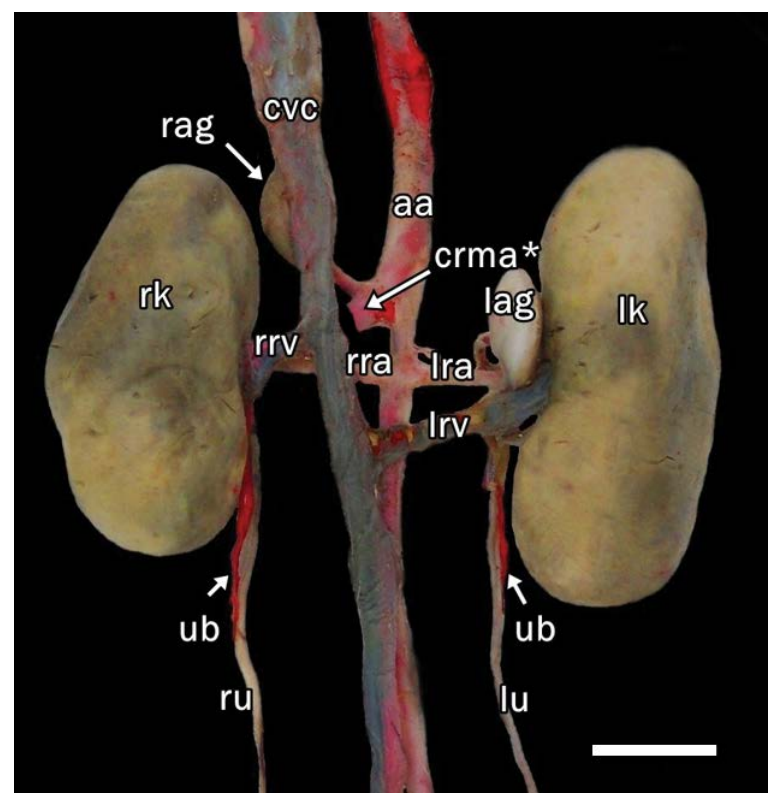

Figure 1. Ventral view of both kidneys and renal vessels in a female specimen of Didelphis aurita; aa - aorta artery; crma — cranial mesenteric artery; cvc — caudal vena cava; lag — left adrenal gland; lk — left kidney; Ira — left renal artery; Irv — left renal vein; lu — left ureter; rag — right adrenal gland; rk — right kidney; rra — right renal artery; rrv — right renal vein; ru — right ureter; ub - ureteral branch. Scale bar: $20 \mathrm{~mm}$.

surface, and devoid of lobation. Measurements of the kidneys and renal vessels of $D$. aurita did not differ between males and females (Table 1). The means of length, width, thickness and volume also did not differ significantly between the left and right kidneys $(p=0.08, p=0.18, p=0.81$ and $p=0.91$, respectively). In contrast, the mean length of the right renal artery was longer than the left $(p<0.01)$ and the left renal vein longer than the right $(p<0.01)$ and the corresponding contralateral vessels. When comparing the measurements of kidneys and renal vessels between antimeres in same-sex individuals (Table 2), it was observed that the length of the right and left renal arteries and the right and left renal veins differed significantly in males $(p<0.01)$. In females, only the length of the renal veins differed $(p<0.01)$ (Tables 1,2$)$.

The most frequent skeletopy of the right kidney was at T13-L2 level (58.6\%), while the skeletopy of the left kidney was between L1-L3 (41.4\%) (Table 3). However, in both sexes were found right kidneys whose cranial pole was at the level of T12 (20.7\%) and kidneys of females with caudal pole at the level of L4 (6.9\%) (Table 3).

All measurements of both kidneys showed a positive linear correlation, moderate to high and significant, with the rostrum-sacral length $(r>0.5$,
Table 1. Mean and standard deviation (in $\mathrm{mm}$ ) of kidney and renal vessels measurements of Didelphis aurita $(n=29)$, separated by sex

\begin{tabular}{|c|c|c|c|c|}
\hline $\begin{array}{l}\text { Measurement } \\
{[\mathrm{mm}]}\end{array}$ & $\begin{array}{c}\text { All } \\
\text { specimens } \\
(\mathrm{n}=29)\end{array}$ & $\begin{array}{c}\text { Male } \\
(n=14)\end{array}$ & $\begin{array}{l}\text { Female } \\
(n=15)\end{array}$ & $\mathbf{P}$ \\
\hline $\begin{array}{l}\text { Length of the right } \\
\text { kidney }\end{array}$ & $28.6 \pm 5.0$ & $27.7 \pm 3.8$ & $29.4 \pm 6.0$ & 0.40 \\
\hline $\begin{array}{l}\text { Length of the left } \\
\text { kidney }\end{array}$ & $31.0 \pm 3.8$ & $29.9 \pm 3.3$ & $31.9 \pm 4.3$ & 0.29 \\
\hline $\begin{array}{l}\text { Width of the right } \\
\text { kidney }\end{array}$ & $15.6 \pm 2.9$ & $15.2 \pm 2.6$ & $16.0 \pm 3.2$ & 0.53 \\
\hline $\begin{array}{l}\text { Width of the left } \\
\text { kidney }\end{array}$ & $14.5 \pm 3.6$ & $13.9 \pm 3.2$ & $15.0 \pm 4.0$ & 0.43 \\
\hline $\begin{array}{l}\text { Thickness of the } \\
\text { right kidney }\end{array}$ & $12.8 \pm 3.0$ & $12.2 \pm 2.2$ & $13.3 \pm 3.6$ & 0.36 \\
\hline $\begin{array}{l}\text { Thickness of the left } \\
\text { kidney }\end{array}$ & $12.6 \pm 2.6$ & $12.3 \pm 2.8$ & $12.8 \pm 2.6$ & 0.60 \\
\hline $\begin{array}{l}\text { Ellipsoid volume of } \\
\text { the right kidney }\left[\mathrm{cm}^{3}\right]\end{array}$ & $3.3 \pm 2.4$ & $2.8 \pm 1.1$ & $3.7 \pm 3.1$ & 0.33 \\
\hline $\begin{array}{l}\text { Ellipsoid volume of } \\
\text { the left kidney }\left[\mathrm{cm}^{3}\right]\end{array}$ & $3.2 \pm 2.2$ & $2.8 \pm 1.4$ & $3.6 \pm 2.8$ & 0.38 \\
\hline $\begin{array}{l}\text { Length of the right } \\
\text { renal artery }\end{array}$ & $13.2 \pm 2.6$ & $13.5 \pm 3.0$ & $12.9 \pm 2.2$ & 0.50 \\
\hline $\begin{array}{l}\text { Length of the left } \\
\text { renal artery }\end{array}$ & $10.7 \pm 2.3$ & $10.2 \pm 2.0$ & $11.1 \pm 2.5$ & 0.32 \\
\hline $\begin{array}{l}\text { Length of the right } \\
\text { renal vein }\end{array}$ & $7.0 \pm 2.3$ & $7.3 \pm 2.4$ & $6.8 \pm 2.3$ & 0.60 \\
\hline $\begin{array}{l}\text { Length of the left } \\
\text { renal vein }\end{array}$ & $13.9 \pm 3.5$ & $14.4 \pm 2.5$ & $13.5 \pm 4.2$ & 0.47 \\
\hline
\end{tabular}

The p-value refers to the unpaired Student's t-test to compare means between sexes.

Table 2. P-value in the comparison of kidney and kidney vessels measurements between antimeres in same-sex animals

\begin{tabular}{lcc}
\hline Measurement [mm] & $\begin{array}{c}\text { Male } \\
(\mathbf{n}=14)\end{array}$ & $\begin{array}{c}\text { Female } \\
(\mathbf{n}=15)\end{array}$ \\
\hline Length of the kidneys & 0.15 & 0.24 \\
Width of the kidneys & 0.22 & 0.47 \\
Thickness of the kidney & 0.91 & 0.71 \\
Ellipsoid volume of the kidneys $\left[\mathrm{cm}^{3}\right]$ & 0.98 & 0.91 \\
Length of the renal arteries & $<0.01^{*}$ & 0.06 \\
Length of the renal veins & $<0.01^{*}$ & $<0.01^{*}$ \\
\hline
\end{tabular}

*Significant difference $(p<0.05)$

$p<0.01)$, with the exception of the length of the left renal artery $(r=0.24, p=0.22)$ (Fig. 2).

\section{DISCUSSION}

Morphometry based on linear measurements of anatomical structures of different organisms is useful to characterise proportions and define parameters of 
Table 3. Absolute and percentage frequencies of right and left kidney skeletopy, separated by sex in Didelphis aurita $(\mathrm{n}=29$ )

\begin{tabular}{lccccc}
\hline \multirow{2}{*}{ Skeletopy } & \multicolumn{2}{c}{ Males $(\mathbf{n}=\mathbf{1 4})$} & & \multicolumn{2}{c}{ Females $(\mathbf{n}=15)$} \\
\cline { 2 - 3 } \cline { 5 - 6 } & Right & Left & & Right & Left \\
\hline T12-L2 & $4(29 \%)$ & - & & $2(13 \%)$ & - \\
T13-L1 & - & - & & $1(07 \%)$ & - \\
T13-L2 & $9(64 \%)$ & $6(43 \%)$ & & $8(54 \%)$ & $1(07 \%)$ \\
T13-L3 & $1(07 \%)$ & $2(14 \%)$ & & $2(13 \%)$ & $3(20 \%)$ \\
L1-L3 & - & $5(36 \%)$ & & $2(13 \%)$ & $7(47 \%)$ \\
L1-L4 & - & $1(07 \%)$ & & - & $2(13 \%)$ \\
L2-L4 & - & - & & - & $2(13 \%)$ \\
\hline
\end{tabular}

normality [23]. The length of the kidneys of $D$. aurita corresponded between $6 \%$ and $8 \%$ of the rostrum-sacral length of the specimens. This percentage can be extrapolated as a reference for individuals of $D$. aurita of different sizes, since the linear correlation between the rostrum-sacral length and the renal measures was positive and significant for all renal measures. In domestic cats and in the canid Lycalopex gymnocercus there was a positive correlation between the rostrum-sacral length and renal volume [30, 32]. In domestic dogs, there was a correlation between the size of the kidneys and the body mass of the animals [27].

In the comparison with mammals of approximate size, the kidneys of $D$. aurita had smaller measurements and ellipsoid volume than the average of do- mestic dogs $(60-90 \times 40-50 \times 30 \times 40 \mathrm{~mm})$ [27], L. gymnocercus $\left(45 \times 24 \times 21 \mathrm{~mm}\right.$ and $\left.11-12 \mathrm{~cm}^{3}\right)$ [30], of domestic cats $(38-44 \times 24-31 \times 20-25 \mathrm{~mm}$ and 9-12 $\mathrm{cm}^{3}$ ) [32] and slightly larger than the mustelid Mustela putorius furo $(24-30 \times 12-13.5 \times 11$ $\times 13.5 \mathrm{~mm}$ ) [10].

The mean length of the left kidney $(31 \mathrm{~mm})$ was higher than the right one $(28.6 \mathrm{~mm})$, although there was no significant difference in the comparison between the averages of both kidneys ( $p=0.08$ ). In domestic dogs, no differences were observed in the dimensions between right and left kidneys [27], as well as in New Zealand rabbits [28] and domestic cats [32]. In the wild canid L. gymnocercus, there was also a tendency, although not significant, of the left kidney to be longer $(p<0.06)$ and wider $(p<0.07)$ than the right one [30]. In humans, the left kidney is larger in both length [12, 21, 25, 26] and width [16].

In $D$. aurita, there was also no difference in renal measures between animals of opposite sexes, such as in the domestic dog [27], New Zealand rabbits [28] and L. gymnocercus [30]. This differs from the human species, in which the kidneys are larger in males [21]. In domestic cats the left kidneys have greater length in males [32].

Although the measurement of the kidney in the fresh state was desirable, it would be difficult to obtain a satisfactory sample because $D$. aurita is a wild species. In rabbits, it was evaluated that the

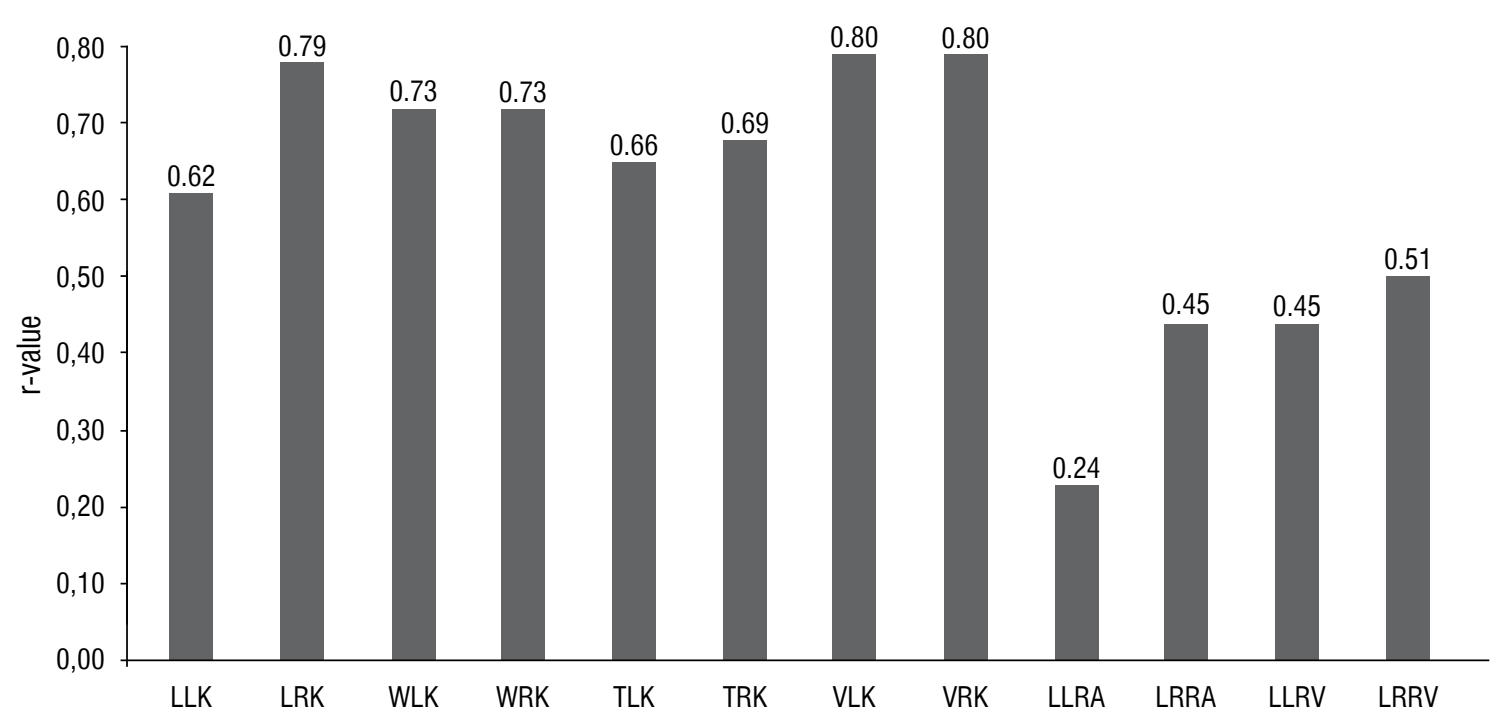

Figure 2. " $r$ " values in Pearson's linear correlation test between rostro-sacral length and renal dimensions in Didelphis aurita $(\mathrm{n}=29)$; LLK — lenght of the left kidney; LRK — lenght of the right kidney; WLK — width of the left kidney; WRK — width of the right kidney; TLK — thickness of the left kidney; TRK — thickness of the right kidney; VLK — volume of the left kidney; VRK — volume of the right kidney; LLRA — lenght of the left renal artery; LRRA — lenght of the right renal artery; LLRV — lenght of the left renal vein; LRRV — lenght of the right renal vein. 
length and width of the rabbit kidneys were unchanged by fixation in formaldehyde solution, while only the height and volume varied from $3 \%$ to $7 \%$ [3]. Therefore, in wild specimens, measuring formaldehyde-preserved kidneys becomes a viable option with a presumptive small distortion margin.

The right renal artery longer than the left in $D$. aurita is explained by the fact that the abdominal aorta is located to the left of the median plane. Similarly, the left renal vein was longer by the position of the caudal vena cava to the right of the median plane. This observation was recorded in domestic dogs [11] and L. gymnocercus [30]. However, in New Zealand rabbits $[1,28]$ the right renal artery is smaller than the left.

The skeletopy of the right kidney was always cranial in relation to the left, even leaving a renal impression of the liver. Because of this positioning, the right renal vessels also exhibited a more cranial location than the contralateral ones. This observation is quite consistent in mammals $[3,7,28,32]$, with the exception of pigs, where the left kidney is more cranial in most cases $[17,29]$.

The skeletopy of the right kidney was the same (T13-L1) in more than half of the cases (58.6\%), while the most frequent left kidney skeletopy (L1-L3) occurred in less than half (41.6\%). Therefore, the skeletopy of the left kidney was more variable. Possibly, the right kidney has less room for accommodation due to the cranial restriction imposed by the relationship with the liver. This would explain the smaller variation of skeletopy and possibly the shorter length of the right kidney compared to the left.

\section{CONCLUSIONS}

The kidneys of $D$. aurita retain characteristics found in other mammal species, such as retroperitoneal localisation, more cranial level positioning of the right kidney and dimensions that did not differ between sexes or antimeres. The results of the present study can support procedures in wild animal medicine and pathological or experimental findings in this species.

\section{Acknowledgements}

This study was financed in part by National Council of Technological and Scientific Development (CNPq), Rio de Janeiro State Research Foundation (FAPERJ) and Coordination of Superior Level Staff Improvement (CAPES) Finance Code 001.

\section{REFERENCES}

1. Ahasan A, Islam MS, Kabria A, et al. Major variation in branches of the abdominal aorta in New Zealand white rabbit (Orycotolagus cuniculus). Int J Nat Sci. 2013; 2(4): 91-98, doi: 10.3329/ijns.v2i4.13218.

2. Barone R. Comparative anatomy of domestic mammals: Angiology. 2nd ed. Vigot, Paris 1996.

3. Bolat $D$, Bahar S, Selçuk ML, et al. Morphometric investigations of fresh and fixed rabbit kidney. Eurasian J Vet Sci. 2011; 27(3): 149-154.

4. Brown BE. Atlas of new world marsupials. Fieldiana Zoology New Series, Chicago 2004.

5. Cáceres NC, Monteiro-Filho ELA. Reproductive biology of the common opossum, Didelphis marsupialis (Mammalia, Marsupialia), in southern Brazil. Brenesia. 1997; 47: 117-122.

6. Cerqueira R, Lemos B. Morphometric differentiation between Neotropical black-eared opossums, Didelphis marsupialis and D. aurita (Didelphimorphia, Didelphidae). Mammalia. 2000; 64(3), doi: 10.1515/ mamm.2000.64.3.319.

7. Culau POV, Azambuja RC, Campos R. Ramos colaterais viscerais da artéria aorta abdominal em Myocastor coypus (nutria). Acta Sci Vet. 2008; 36(3): 241-247.

8. D'Andrea PS, Roque ALR, Teixeira BR. Alternativas para Animais de Laboratório: uso de animais não-convencionais - roedores silvestres. In: Andrade A, Pinto SC, Oliveira RS (Eds.). Animais de Laboratório: criação e experimentação. Editora Fiocruz, Rio de Janeiro 2002: 353-360.

9. Elkin M. Radiology of the urinary system. Little, Brown and Company, Boston 1980.

10. Evans H, An N. Anatomy of the Ferret. Biology and Diseases of the Ferret. Wiley Online Library, Hoboken. 2014: 23-67, doi: 10.1002/9781118782699.ch2.

11. Evans HE, DeLahunta A. Miller's Anatomy of the Dog. $4^{\mathrm{a}}$ ed. Elsevier, St. Louis 2013.

12. Fernandes MM, Lemos CC, Lopes GS, et al. Normal renal dimensions in a specific population. Int Braz J Urol. 2002; 28(6): 510-515.

13. Fonseca $G A B$, Herrman $G$, Leite $Y L R$, Mittermeier RA, Rylands $A B$, Patton JL. Lista anotada dos mamíferos do Brasil. $4^{\circ}$ Ed. Conservation International \& Fundação Biodiversitas, Belo Horizonte 1996.

14. Gardner AL. OrderDidelphimorphia. In:WilsonDE, ReederDM. (Eds.) Mammal species of the world: a taxonomic and geographic reference. 2nd ed. Smithsonian Institution Press, Washington DC 1993: 15-23.

15. Graipel ME, Santos-Filhos M. Reprodução e dinâmica populacional de Didelphis aurita Wied-Neuwied (Mammalia: Didelphimorphia) em ambiente periurbano na llha de Santa Catarina, Sul do Brasil. Biotemas. 2006; 19(1): 65-73.

16. Gupta S, Devi ND, Sinam SS, et al. Ultrasonographic renal dimensions in normal adult population of North-East India. Int J Med Health Sci. 2013; 2(4): 433-437.

17. König HE, Maierl J, Liebich HG. Sistema Urinário (Systema Urinarium). In: Liebich HG (eds.). Anatomia dos Animais Domésticos: Texto e atlas colorido. 6 Ed. Artmed, Porto Alegre 2016: 399-412.

18. Lemos B, Cerqueira R. Morphological differentiation in the white-eared opossum group (Didelphidae: 
Didelphis). J Mammal. 2002; 83(2): 354-369, doi: 10.1644/1545-1542(2002)083<0354:mditwe>2.0.co;2.

19. Liapis H, Vogler G, Steinhardt GF. North American opossum Didelphis virginiana as a fetal nephrotoxicity model: histologic and ultrastructural assessment of uranyl nitrate (UN)-induced damage. Microsc Res Tech. 1997; 39(3): 285-296, doi: 10.1002/(SICI)10970029(19971101)39:3<285::AID-JEMT7>3.0.CO;2-J, indexed in Pubmed: 9372500.

20. Möell H. Size of normal kidneys. Acta Radiol. 1956; 46(5): 640-645, indexed in Pubmed: 13381548.

21. Oyuela-Carrasco J, Rodríguez-Castellanos F, Kimura E, et al. [Renal length measured by ultrasound in adult mexican population]. Nefrologia. 2009; 29(1): 30-34.

22. Paglia AP, Fonseca GAB, Rylands AB, Herrmann G, Aguiar LMS, Chiarello AG, Leite YLR, Costa LP, Siciliano S, Kierulff MCM, Mendes SL, Tavares VC, Mittermeier RA, Patton JL. Lista Anotada dos Mamíferos do Brasil / Annotated Cheklist of Brazilian Mammals. $2^{\mathrm{a}}$ ed. Conservation International, Arlington 2012.

23. Peters $M$, Jäncke $L$, Zilles $K$. Comparison of overall brain volume and midsagittal corpus callosum surface area as obtained from NMR scans and direct anatomical measures: a within-subject study on autopsy brains. Neuropsychologia. 2000; 38(10): 1375-1381, doi: 10.1016/s00283932(00)00048-8.

24. Reis NR, Peracchi AL, Pedro WA, Lima IP. Mamíferos do Brasil. Nelio Reis, Londrina 2006.

25. Sampaio FJ, Mandarim-de-Lacerda CA. [Morphometry of the kidney. Applied study in urology and imaging]. J Urol (Paris). 1989; 95(2): 77-80, indexed in Pubmed: 2659677.
Sampaio FJ. Theoretical kidney volume versus real kidney volume: comparative evaluation in fetuses. Surg Radiol Anat. 1995; 17(1): 71-75, doi: 10.1007/BF01629504, indexed in Pubmed: 7597570.

26. Sampaio K, Araújo RB. Ultra-sonografia de características lineares e estimativas do volume de rins de cães. Arq Bras Med Vet Zootec. 2002; 54(3): 248-254, doi: 10.1590/ s0102-09352002000300005.

27. Santos-Sousa CA, Stocco AV, Mencalha R, et al. Morphometry and vascularization of the rabbit kidneys (Oryctolagus cuniculus). Int J Morphol. 2015; 33(4): 1293-1298, doi: 10.4067/s0717-95022015000400017.

28. Sisson S. Sistema urogenital do suíno. In: Getty R. (Ed.) Anatomia dos Animais Domésticos. 5. ed. Guanabara Koogan, Rio de Janeiro 1986: 1216-1221.

29. Souza EC, Leao Neto LF, Santos EAR, et al. Caracterización anatómica de los riñones del Zorro Pampeano (Lycalopex gymnocercus): morfometría y vasos renales. Rev Electrón Vet. 2018; 19: 1-8.

30. Steinhardt G, Salinas-Madrigal L, Farber R, et al. Experimental Ureteral Obstruction in the Fetal Opossum. I. Renal Functional Assessment. J Urol. 1990; 144(2 Part 2): 564-566, doi: 10.1016/s0022-5347(17)39524-1.

31. Stocco AV, Sousa C, Gomes MS, et al. Is there a difference between the right and left kidney? A macroscopic approach in Brazilian Shorthair Cat. Arq Bras Med Vet Zootec. 2016; 68(5): 1137-1144, doi: 10.1590/1678-4162-8339.

32. Ventura J, Salazar M, Pérez-Hernández R, et al. Morphometrics of the genus didelphis (didelphimorphia: didelphidae) in venezuela. J Mammal. 2002; 83(4): 1087-1096, doi: 10.1644/1545-1542(2002)083<1087:motgdd >2.0.co;2. 